\title{
From enforceability to feel-good: notes on the pre-history of the recent treaty debate
}

Tim Rowse

On 26 April 1979, Dr HC Coombs called together a number of friends and colleagues in Canberra to discuss a new approach to the public debate about Indigenous affairs. Five months earlier, he had circulated a memo in which he observed a faltering in the pace of reform in Aboriginal affairs. What could he and his friends do to sustain and to entrench the reforms initiated in the 1970s? One of those friends, Judith Wright, later recalled that they agreed to form the 'Aboriginal Treaty Committee, whose objectives would include:

- the establishment of exclusive Commonwealth responsibility for all

Aboriginal matters (as against the States);

- pressure for a treaty as providing a kind of constitutional basis for the relationship of Aboriginal Australians to the Commonwealth and Australian society generally;

- providing a focus for white political support for the Aboriginal cause. ${ }^{1}$

In reviewing what the Aboriginal Treaty Committee did, I want to underline the first of these objectives - the assertion of Commonwealth power over the States. Below I will suggest why the Aboriginal Treaty Committee conceived of Commonwealth power 'as against the States'. Here I will confine myself to the observation that the question of Australia's federalism can never be far away when issues of justice for Indigenous Australians are being discussed.

\section{Two competing conceptions of social justice}

It is a useful simplification of the discussion of Australian Indigenous needs and aspirations in the first few years of the twenty-first century to distinguish two tendencies in the understanding of 'social justice'. On the one hand, we have the strong advocacy of a treaty. This is based on a conception of distinct Indigenous rights, and it has often been associated with a wish to subordinate States and Territories to a Commonwealth that is committed to Indigenous rights. In 2000, for example, Bill Jonas, the Aboriginal and Torres Strait Islander Social Justice Commissioner and a treaty advocate, recommended that the Commonwealth amend the Commonwealth Grants Commission Act 1973 to require it to enquire, every two years, into State and Territory performance of their responsibilities towards Indigenous Australians. ${ }^{2}$ In arguing for this proposal, Dr Jonas noted a House of Representatives Standing Committee comment that, in health service delivery, framework agreements among Australian governments have been mere 'gentleman's agreements that apply in principle only and for which there is no recourse if breached'. ${ }^{3}$ The Social Justice Commissioner's human rights approach sought to

\footnotetext{
${ }^{1}$ Wright 1985: 106. Those present were: Coombs, Wright, Stewart $\quad{ }^{2}$ Aboriginal and Torres Strait Islander Social

Harris, Charles Rowley, WEH Stanner and Dymphna Clark. Justice Commissioner 2001: 131-2.

Wright, 1985: 103, refers to the four men as the 'core members'. $\quad 3$ Aboriginal and Torres Strait Islander Social Justice

Commissioner 2001: 90.
} 
make the States and Territories accountable to the Commonwealth; the Commonwealth is, in turn, internationally accountable by virtue of its commitment to various global human rights conventions and protocols.

The rival conception of social justice is associated with an ideal of 'cooperative federalism'. Since 1992, COAG - the Council of Australian Governments - has been promoted by all governments as the forum in which to plan a national approach to Indigenous policy. The Council for Aboriginal Reconciliation (CAR) acknowledged COAG's eminence when its final report Reconciliation: Australia's challenge (2000) included the recommendation that:

[COAG] agree to implement and monitor a national framework whereby all governments and the Aboriginal and Torres Strait Islander Commission (ATSIC) work to overcome Aboriginal and Torres Strait Islander people's disadvantage through setting program performance benchmarks that are measurable (including timelines), are agreed in partnership with Aboriginal and Torres Strait Islander peoples and communities, and are publicly reported. ${ }^{4}$

This recommendation pointed to the common ground that had emerged in the 1990s - what the Howard government has come to call 'practical reconciliation'. This is a powerful notion because it appeals to so many of the ideas held by both Indigenous Australians and their wellwishers about what is necessary to a happy life for Australians. However, because it makes no concessions to the argument that Indigenous Australians have rights that are specifically 'Indigenous rights', this focus on social indicators of 'disadvantage' is - to treaty advocates - necessary but not sufficient, and - to treaty opponents - quite sufficient. So the current (2004) climate of debate on Indigenous affairs is characterised both by common ground and by polarity.

In this paper I wish to foreground the polarity that has become characteristic of Australian debate: treaty/Indigenous rights/Commonwealth ascendancy versus a 'practical reconciliation' based on cooperative federalism and attaching no significance to 'Indigenous rights'. So pervasively did this polarity structure the discussion of Indigenous Australians' aspirations between the years 2000 and 2004 that it neutralised the long-nurtured doctrine of 'reconciliation'. That term was invoked by both sides of the polarity, so that it became a meaningless, or at least a question-begging, item of cant. No one could be against 'reconciliation', if being for reconciliation embraced such a diversity of views about the rights of Indigenous Australians and about the accountability of governments.

The ultimate purpose of the following historical notes is to remind readers of the ways that discussion about a possible treaty should always be entangled with a view of Commonwealth responsibilities within the federation. However, that our treaty debate cannot or should not avoid issues of federalism was more obvious in the early 1980s than in 2000. As I will show, by 2000 , due in part to the characteristic vagueness of the language of 'reconciliation', the discussion had become less about the forms of 'state' and more about the moral and emotional constituents of the 'nation'. 
First let us go back to the years 1979-83, when the Aboriginal Treaty Committee (ATC) and the National Aboriginal Conference (NAC) stimulated the first phase of the Australian discussion of a treaty with Indigenous peoples. Then I will illustrate the way that 'reconciliation' muddied the waters by shifting the discourse away from questions of government machinery to considerations of national 'healing'.

\section{The Aboriginal Treaty Committee 1979-83}

The Aboriginal Treaty Committee's campaign, 1979-83, consisted of four elements: a publications programme, a series of public appearances by such ATC 'stars' as the committee's chair Dr HC Coombs, a university-based research program, and the encouragement of local activities.

The ATC's publications program began with Stewart Harris's book 'It's Coming Yet'... An Aboriginal Treaty, published in 1979. On 17 January 1980 Don Dunstan launched it, and on 26 March 1980, the ABC's Broadband program was devoted to the book and to the Treaty proposal. A copy was given to every person who had donated $\$ 5.00$ or more in response to the National Times advertisement in August 1979. 'It's Coming Yet' quickly exhausted the first print run of 5000. On 20 May 1980, twelve months after its first formal meeting, the Committee published its first Newsletter, over Coombs's signature. By October 1980, the Committee could send a copy of the second newsletter to some 2000 addresses. In April 1981, the Newsletter was replaced by a registered quarterly, printed tabloid size, Aboriginal Treaty News. The Committee published nine editions of the News, the last in October 1983. By then it had progressed from offset 'scissors and paste' to a professionally typeset page, with photographs and maps in an orderly and pleasing layout. In its final issue the News was showing signs of evolving from social movement newspaper to something more rarefied; it carried articles of such length and erudition - Russell Barsh's 'International law and the Miqmaq', Douglas Sanders's 'Indigenous issues in international law' - that the Committee now seemed to be selectively addressing the more academically inclined of its supporters. This was a measure of their success in at least one of their aims: to promote within Australia serious deliberation on the legal instruments available to nation states and Indigenous peoples seeking just settlements.

Universities were essential sites for the Committee's work. There the concept of a treaty could be clarified and made respectable in seminars and conferences. On 4 June 1980 Charles Rowley addressed an ANU convocation luncheon on 'Why a Treaty with the Aborigines?' On 17 July 1980 Gervaise Coles of the legal section of the Department of Foreign Affairs joined Coombs, Robert O'Neill and Ralph Harry in a colloquium on the Treaty at the ANU. The second Newsletter foreshadowed similar activities at Mt Lawley CAE, James Cook University and the Universities of Western Australia, New South Wales and Sydney: 'Dr. Coombs has been initiating most of these conferences'. ${ }^{5}$ By April 1982 the Committee could claim to have instigated twelve conferences and seminars exploring the justification and means for a treaty over the 36 months since its inception. ${ }^{6}$ Coombs saw the Committee's work as a research programme in law and in history, as much as he saw it as a media-based pitch for 'public opinion'. The university-based strand of the Committee's work culminated in a November 1983 conference at the ANU on the application of international law to Indigenous rights in Australia and North America.

\footnotetext{
${ }^{5}$ The Aboriginal Treaty Committee Newsletter 2. $\quad{ }^{6}$ Coombs to Senator Alan Missen 7/4/82, in Commonwealth of Australia (Senate) papers

${ }^{7}$ Aboriginal Treaty Committee 1979. 1983: 568-9.
} 
Although Coombs was not the only Committee member to speak publicly on their work, he seems to have carried most of the burden of public appearances. He had commenced the campaign in 1979 with three well-reported public addresses. On July 8 1980, he joined Roberta Sykes and Tom Kenneally on John Singleton's TV chat show. In June 1980, the National Times (8-14 June) carried, in their 'Other Voices' column, one of Coombs's 1979 speeches, his Amnesty address of December 1979. The National Times, in which the Committee had displayed its original manifesto as a paid advertisement, ${ }^{7}$ seems to have been the Committee's most important vehicle. Coombs found interest as well from the editors of Social Alternatives, The Catholic Leader and the Sydney Morning Herald. Indeed a feature article by the Committee published in the Herald won for the ATC a gold citation in the UN Media Peace Prize project. These writings repeated the arguments laid out in Coombs's opening addresses of 1979. The Herald article was notable for its concluding appeal to a sense of national occasion.

In 1988 we celebrate the 200th anniversary of the original British settlement. Do we want that anniversary to be a day of mourning and of hatred for Aboriginal Australians? What a splendid component of that anniversary would be a celebration also of the conclusion of a freely negotiated treaty in which Aboriginal rights were acknowledged, just compensation awarded and Aboriginal status in our society honoured. ${ }^{8}$

While advocating the Treaty, the Committee also helped to publicise any reports or studies that drew attention to the deficient performances of governments and/or to the means to better government. Thus the Committee paid for space in the Age on 30 September 1981, inviting those attending the Commonwealth Heads of Government meeting to study the Report of the World Council of Churches Team visit to Australia, June-July 1981; the Reports of the NSW Parliamentary Select Committee on Aborigines, 1980 and 1981; the Reports of the Commonwealth Parliamentary Committee on Aboriginal Health (1979) and Aboriginal Legal Aid (1980); and the Reports of the Commissioner for Community Relations in 1980 and 1981. On 13 August 1981, Coombs wrote to 35 newspapers arguing that the World Council of Churches report on conditions in Aboriginal Australia added to the justification for a treaty.

In the Committee's own organ, Aboriginal Treaty News, it could control the representation of the public debate it was stimulating. The first issue featured on its front page a photo of the mayor of the Gold Coast, Keith Hunt, marking Australia Day 1981 by signing the Treaty Supporters' form. Judith Wright contributed an article urging other local support groups to follow the Gold Coast group in organising similar events. From later issues the reader could learn that the Fremantle City Council had formally recognised that its area had once belonged exclusively to Aboriginal people and that Dymphna Clark had persuaded 62 artists to donate work to a Sydney fund-raising exhibition 'Ab Origine', opened by her husband Manning and by Margaret Valadian at the National Trust Centre, Sydney, on 9 January 1981.

Coombs's public speaking engagements continued throughout 1981. In May, he and Rowley took part in a half-day ANZAAS Symposium at the University of Queensland. On 14 June, Coombs was the guest speaker at a joint meeting of the local committees of Pymble and Gordon, and at the end of August he accompanied Judith Wright to Townsville for a conference at James Cook University on 'Prospects for Change'. At the invitation of Senator Susan Ryan, Coombs

\footnotetext{
${ }^{7}$ Aboriginal Treaty Committee 1979. $\quad{ }^{8}$ Sydney Morning Herald 27 November 1980.
} 
and Rowley met with the ALP's national policy committee on Aboriginal affairs on 12 October 1981. Coombs continued throughout 1982 to accept engagements on the Committee's behalf. They included visits to Perth and Geelong in March, and a two-day trip in May to Tasmania, where he addressed a university audience and a Tasmanian writers' luncheon. It was a measure of the impact of the Treaty debate that on 30 September 1981 Senator Missen had announced an inquiry by the Standing Committee on Constitutional and Legal Affairs into the feasibility of a formal agreement between the Commonwealth and Aboriginal people. On 22 June 1982, several members of the Committee (Rowley, Wright, Diane Barwick and Stewart Harris) appeared with their legal consultant Peter Bayne before the Standing Committee. Coombs made his appearance on 9 September 1982.

\section{Land rights and the States}

Though treaty advocates mentioned the means of 'practical reconciliation' (as they would later be called) - such as housing, community infrastructure, schools and medical services - one issue of 'Indigenous rights' continued, at this time, to overshadow all others: land. By the early 1980 s, there had been strong public interest for almost 20 years in the controversies generated by Aboriginal land claims against the Commonwealth and by the Commonwealth's responses: the Yirrkala petition in 1963, the Gurindji walk-off in 1966-67, the Yolngu court action of 1968-71 and then the land rights bills of the Whitlam (1973-75) and Fraser (1975-83) governments that resulted in the Aboriginal Land Rights (Northern Territory) Act 1976. In this sequence of challenges and responses the State governments had been all but invisible, as the Commonwealth set what reformers such as Coombs hoped would be an exemplary pattern of recognition of Indigenous rights. However, in the late 1970s, two States asserted the limits of their cooperation with Commonwealth initiatives that affected their own land administration. In their responses to the Commonwealth's attempt to purchase the Archer River pastoral lease for its Aboriginal owners, the Queensland government blocked the sale, declaring land rights to be contrary to State policy. The case went to the High Court and was resolved in the Commonwealth's favour in 1982 (Koowarta v Bjelke-Petersen). ${ }^{9}$ In Western Australia, one remote group of Aborigines seemed to have achieved security when the Noonkanbah pastoral lease had been transferred to Aboriginal ownership in 1975. However, the Court government sought to oblige the new owners to accept petroleum exploration on their property. The owners' resistance aroused considerable public sympathy in 1979 and 1980. The Federal Minister for Aboriginal Affairs, Fred Chaney, was openly critical of the Western Australian government for insisting that minerals exploration prevail over Indigenous land owners' wishes. However, the Noonkanbah dispute demonstrated to advocates of land rights that the Commonwealth was not willing to challenge 'States rights' over land use.

The Fraser government also looked weak when challenged by Queensland. In 1978 the Commonwealth had attempted to flex its constitutional muscles in a 1978 law providing for self-determination on Queensland's reserves. ${ }^{10}$ Before the legislation could come into effect, the Queensland government de-gazetted the reserves and declared them to be shires. The Fraser government declined to counter this move, and nor would it respond to requests from the remaining Queensland reserves (for example, Yarrabah) for help in implementing land rights and self-management. By 1980 the Queensland and Western Australian governments had prevailed politically over the Commonwealth, even though the Commonwealth had the constitutional authority to enforce a national land rights policy. Frank Brennan and James

${ }^{9}$ (1982) 153 CLR $168 . \quad{ }^{10}$ Aboriginal and Torres Strait Islanders (Queensland Reserves and Communities Self-Management) Act 1978 (Cth). 
Crawford concluded in a 1990 paper that, notwithstanding the 1967 referendum, there remains a 'hidden constitution' in which Commonwealth power remains limited and residual to the land-use powers of the States. ${ }^{11}$ To any interested observer, the pre-eminence of 'States rights' over Indigenous rights had become clear by the time Coombs and his colleagues were into their first year of treaty advocacy.

The ATC therefore had frequent opportunity to argue for some abiding national framework of enforceable fairness. On 27 July 1980, the National Times carried the Committee's advertisement appealing for a five-year moratorium on prospecting and mining in the Kimberley and in other areas 'predominantly occupied by Aboriginal Australians'. The ATC's second Newsletter told supporters that Coombs had also written to the Western Australian Premier, Sir Charles Court, on April 30 1980, 'asking him to accept the Noonkanbah people's proposal for a three year moratorium and to set up an independent Commission to consider the application of the Woodward Commission's principles to Western Australia'. The Committee called upon the Minister for Aboriginal Affairs Chaney to resign over Noonkanbah, and Coombs also wrote to the B'nai B'rith organisation in Washington to suggest that it would be a mistake to award Fraser a medal for his 'humanitarian' services: Fraser's 'record in his own country denies his suitability for it'. ${ }^{12}$ Coombs also spoke at a preview of a film on the Noonkanbah dispute $O n$ Sacred Ground. 'There are going to be a succession of Noonkanbahs unless Land rights laws are passed so that the Federal Government will intervene', he told the audience. ${ }^{13}$

The Queensland government also attracted the Committee's scrutiny. In June 1980 Coombs published a letter in the Courier Mail warning delegates to the second World Wilderness Congress in Cairns that the Bjelke-Petersen government, in order to pre-empt Aboriginal land claims, might seek their support for a national park in Cape York. In March and May 1981 the Committee paid for an advertisement in the National Times pointing out that the Queensland government was planning to alienate remnant reserves from their residents. The Commonwealth had the authority to acquire the reserves compulsorily and to vest them in these communities, the advertisement pointed out, but would it use that power? On 27 May 1980 Coombs wrote to Fraser of his concerns about Queensland reserves, and in July he got a letter into the Age on this issue and made himself available for media interviews. ${ }^{14}$

Most of Aboriginal Treaty News nos 3 (November 1981), 4 (February 1982) and 5 (May-August 1982) comprised running State-by-State commentaries on land rights - abuses, laws and policy developments. Some of the commentary was written (anonymously) by Committee members; other material consisted of reprints of news stories, feature articles and editorials from the daily newspapers, with the Age, the Canberra Times and the Courier Mail particularly prominent. Aboriginal Treaty News no 6 (September-October 1982) was a special edition to mark the protests against the Queensland government while it hosted the twelfth Commonwealth Games in Brisbane. The next issue, for the summer of $1982-83,{ }^{15}$ coincided with Fraser's third attempt to seek re-election. In the previous election, October 1980, Coombs had addressed questions to four party leaders and then summarised and criticised their responses. In 1983 he asked: 'Would your Government be prepared to over-ride a State or Northern Territory Government to ensure that land and human rights were provided for Aboriginal Australians?' The Labor Party said that it intended to do so, in Queensland, 'promptly after taking office'; the Coalition

\footnotetext{
${ }^{11}$ Brennan and Crawford 1990.

${ }^{13}$ As quoted in the Canberra Times 9 December 1980.

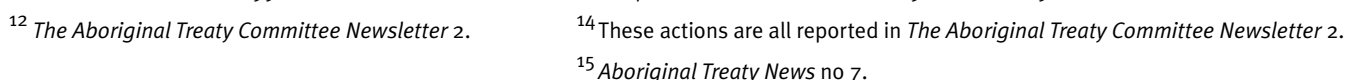


would go no further than to state that the Commonwealth 'has the power to intervene if necessary and appropriate'. ${ }^{16}$ The Committee refrained from advising how to vote, but charged the Fraser government with having 'virtually abdicated its responsibilities for Aboriginal rights and land rights', and with having 'given way on practically all issues to State Governments such as Queensland and Western Australia'. Worse was possibly to come. The Federal government now looked like capitulating to the Northern Territory government's proposed amendments to the Land Rights Act. Stewart Harris wrote that Aboriginal people could not be expected to negotiate a treaty with the Fraser government. The Committee concluded that 'This election will mean hope or despair for Aborigines everywhere'. ${ }^{17}$

\section{A parallel Indigenous treaty campaign}

When Coombs first circulated friends his ideas about a treaty at the end of 1978, he may or may not have been aware that similar ideas were brewing within the National Aboriginal Conference (NAC), the elected advisory body established by the Fraser government in 1977. In April 1979, the same month as Coombs's first informal gathering to discuss his circulated Aboriginal Treaty Committee proposal, the NAC leadership announced that it would seek to negotiate a treaty with the Australian government. Prime Minister Fraser confirmed on 21 August 1979, two days after the Committee had held its first Press conference, that the Minister for Aboriginal Affairs was examining the NAC proposal. From the moment of that announcement, Coombs and the others on the Committee were faced with a delicate political task: how to relate their efforts to the NAC's dealings with the Fraser government?

The Committee's manifesto in the National Times (August 1979) included the outline of a possible procedure for the NAC's dialogue with government. ${ }^{18}$ Soon after it appeared, Coombs wrote to NAC leaders and other Aborigines asking them to comment on the Committee's initial efforts to establish a national debate on the Treaty. Their response was positive. Coombs 'reported at a Committee meeting on 3 September that they were pleased with the wording of the advertisement and the publicity gained through the Press conference. It was agreed that separate campaigns, with exchange of information and publications, offered the best chance of success. ${ }^{19}$ Coombs was later to give an account of his understanding with the NAC:

We do not have Aboriginal members because consultation with the NAC and other Aboriginal organisations made it clear that they would not welcome a joint organisation which could be represented as the instrument of 'white stirrers' and that they wished a Treaty to be achieved as a result of Aboriginal initiative and effort.

They made it equally clear, however, that they would welcome our support and help. ${ }^{20}$

In the autonomy of the two organisations and in the separateness of their campaigns Coombs found room to comment critically on the Indigenous mobilisation. In one of his first speeches, on 2 October 1979, he had aired his doubts about the NAC's present capacity to conduct a Treaty campaign in accordance with the traditions of Aboriginal culture. ${ }^{21}$

On 12 November 1979, the NAC held a Press Conference on their proposal, announcing that they were forming a sub-committee specially to canvass ideas and to develop a draft.

\footnotetext{
${ }^{16}$ Aboriginal Treaty News no $7 . \quad{ }^{18}$ Aboriginal Treaty Committee 1979.

${ }^{20}$ Coombs's responses to a seminar (which he was unable to

${ }^{17}$ Aboriginal Treaty News no $7 . \quad{ }^{19}$ Wright 1985: 121. attend) at the University of Western Australia, 27-28 April 1981. Coombs 1981: 117 .

${ }^{21}$ Coombs 1979 b.
} 
The NAC also announced that the word 'treaty' would be dropped and replaced by a word from the languages of north-east Arnhem Land - makarrata. At the time, makarrata was glossed as 'the resumption of normal relations after a period of hostilities'. The next day, Minister for Aboriginal Affairs Senator Fred Chaney welcomed the NAC's substitution of makarrata for 'treaty'. In the Senate a week later, he explained that the government did not like the term 'treaty' 'because of the implication that one is in some way talking about more than one Australia or more than one nation within Australia'. By discarding 'treaty', the NAC had reassured Chaney that Aborigines and Torres Strait Islanders saw themselves 'as Australians within the Australian nation'. He reported with evident approval the NAC's wish to use 'something like 18 months for the task it has undertaken'. ${ }^{22}$

Judith Wright has recalled that 'We ... were worried by the government's suspicious alacrity over the NAC demand'. ${ }^{23}$ The Aboriginal Treaty Committee had been conceived in apprehension and distrust of the Fraser government, and it had been forthright in its subsequent criticisms, including calling for Chaney's resignation over Noonkanbah. The Committee was now worried by the NAC's shift from 'treaty' to makarrata and by the NAC's short timetable for formulating a treaty. The Aboriginal Treaty Committee could therefore be glad of their policy of keeping some distance from the NAC's campaign. However, this protocol did not oblige them to stay away from Aboriginal people. As Coombs explained to NAC Chair Jim Hagan on 26 May 1980, 'we hoped to invite Aboriginal leaders and others to speak for or against the treaty idea and be tape recorded, so that Aboriginal groups could hear their own people giving different views on the subject'. ${ }^{24}$ For the Aboriginal Treaty Committee to consult Indigenous Australians in this way was consistent with its view that the NAC lacked the resources to sponsor a widespread Indigenous debate.

Meanwhile the NAC had begun its consultations with Indigenous Australians, circulating a leaflet and a questionnaire. Over 19 days in February 1980 Hagan's sub-committee held 15 meetings along the eastern seaboard (from Launceston to Thursday Island) and as far inland as Mt Isa and Mildura. Their efforts were welcomed by the Prime Minister who spoke at a dinner for the NAC on 25 March 1980. In April and May, the NAC's makarrata sub-committee was back on the road, visiting 15 towns and capital cities in Western Australia, South Australia and the Northern Territory over 23 days.

On 2 July 1981 the NAC released an interim report on these consultations at a meeting to which Coombs was invited. The report began by reminding readers that 'the Prime Minister has stated that he is now ready to talk to Aborigines about an Agreement, but he will only talk with the National Aboriginal Conference (NAC), because we are elected representatives of the Aboriginal people'. There followed a series of quite specific proposed treaty terms, including reserved seats for Indigenous Australians in Commonwealth and State parliaments, a quota on employment of Aboriginal people in government 'irrespective of their established skills', and the return of skeletons and artefacts from museums. ${ }^{25}$ Coombs made public his critical response to what was evidently a draft treaty. The NAC should take more time to develop a debate among Indigenous Australians, he urged. Coombs added that the NAC would need far more resources than the Fraser government had so far allowed, if it were to negotiate on equal terms.

\footnotetext{
${ }^{22}$ Commonwealth of Australia Senate Hansard 19 November 1979: 2427 (for both quotations).

${ }^{24}$ The Aboriginal Treaty Committee Newsletter 2.

${ }^{23}$ Wright 1985: 123.

${ }^{25}$ The text of this report was published in

The Catholic Leader 13 July 1980.
} 
Many of the results of the NAC's first consultations seemed to confirm the wisdom of these remarks. Hagan acknowledged in a letter to the Committee that there was division over the term makarrata, with many Aboriginal people preferring 'treaty'. The Aboriginal Treaty Committee gave publicity to these misgivings in its second Newsletter (October 1980). In many places, neither concept was yet familiar enough for Aboriginal people to form an opinion. Discussions so far had unearthed doubts that any agreement, whatever it was called, could soon be forged with the Australian government. Central Australian Aboriginal Congress was claiming that if the process of consultation were to result in the necessary 'consensus' among Aborigines, then at least five years of effort would be required: the NAC did not yet have a mandate for negotiations. The Tasmanian Aboriginal Centre warned against a premature settlement that would nip in the bud an emerging Indigenous political consciousness. 'Any agreement at this point in time will be seen as a charitable one ... Only when we represent such a threat to the stability and power of white Australia that they are forced to negotiate a treaty with us will a Treaty not be viewed as charitable. ${ }^{26}$

The NAC sub-Committee's early consultations had given them reason to reconsider whether eighteen months would be enough time to prepare a treaty. Coombs attempted to reinforce their doubts in a letter on 22 September 1980 to Hagan answering his question as to 'who, or what body, on the Aboriginal side should be considered representative in negotiations'. ${ }^{27}$ Coombs proposed a six step process in which the NAC would first commission and circulate position papers on treaty issues, then call 'a Convention of representatives chosen by recognised Aboriginal organisations, communities and traditional groups' to discuss them. These representatives would then return to their organisations. The NAC would then recall the Convention to consider a first draft of an agreement to be proposed to the Government, and the Convention would remain in existence to respond to the issues arising from the ensuing negotiations. Final approval or rejection would be a decision of this Convention, not of the NAC by itself. Coombs's suggestion accorded the NAC a central but not a singular role in Indigenous representation. Among Aboriginal leaders the timetable of consultations and negotiations was now controversial. In a Townsville forum, on 1 October 1980, the North Queensland Land Council's Mick Miller was in clear disagreement with the NAC's Bill Bird. According to Judith Wright, on the same platform to speak for the Committee, Bird still thought that a document could eventuate within the term of the current government. Miller was among those preparing for the long haul. ${ }^{28}$

Thus the Aboriginal Treaty Committee found itself in the midst of a lively debate among Indigenous people - a debate that it had helped to stir up. While the Committee told supporters that it did not 'want to be seen as influenced by any particular Aboriginal body', it was effectively taking a position in a debate among Indigenous Australians by arguing for more time, by not fully endorsing the term makarrata and - most important of all - by highlighting the Fraser government's failure to face down Queensland's and Western Australia's opposition to land rights. The NAC's hopeful assessment of the Fraser government contrasted with the Committee's growing contempt for that Government. The Committee's editorial policy in Aboriginal Treaty News was to make such differences visible. For example, Barrie Pittock, one of the signatories of the Committee's first advertisement in the National Times, wrote a piece asking 'What is Wrong with a Treaty?' ${ }^{29}$ His suspicions were aroused by the Fraser government's keenness to negotiate

\footnotetext{
${ }^{26}$ The Aboriginal Treaty Committee Newsletter 2: $3 . \quad{ }^{28}$ Wright 1985: 141-2.

${ }^{27}$ As paraphrased by Wright 1985: $155 . \quad 29$ Pittock 1981.
} 
a makarrata. He agreed with Kevin Gilbert's recent assertion that an agreement could be made only between 'two equal sovereign peoples'. A treaty with teeth, detailed and enforceable in the courts, could not be achieved 'next year or the year after - probably not for a decade or more, if ever'. Pittock confessed his uneasiness 'that the Treaty movement originated amongst whites without strong Aboriginal input and seems to have gathered too much superficial support too quickly'. His closing words warned of his conditional continuing support: 'By all means advocate a Treaty, but make sure it has guts!' Coombs took a similar line. On 11 December 1980, he joined Jack Davis in addressing a meeting in Perth on the Treaty. There he argued that 'Aborigines would be at an enormous disadvantage if a Treaty were concluded before all parties were fully informed ... This will take considerable time. ${ }^{30}$

But how much time? Was the Aboriginal Treaty Committee prepared to commit itself to a timetable? This question was taken up on page one of the first issue of the Committee's new Aboriginal Treaty News (April 1981). The Committee judged an agreement unobtainable by Australia Day 1983, as some had suggested. Better to look to the bicentennial year 1988. The possible significance of the Bicentennial thus began to figure in the Committee's strategy of persuading non-Aboriginal Australians that their nationhood was morally flawed. The year 1988 seemed, in 1980-81, to be sufficiently far ahead to accommodate the view that 'years' of consultation and negotiation were required. The timing of the treaty or makarrata negotiations was not the only issue that had to be resolved. The issue of who the parties to negotiation would be was starting to become more complicated. In February and March 1981, the NAC and the Minister for Aboriginal Affairs exchanged letters about the possible contents of a makarrata. In the course of his comments, the Minister made clear the conception of federalism that underlay his friendly disposition towards the makarrata. In effect, he proposed a 'States rights' approach. That is, he noted that the NAC should be negotiating with each of the State governments on those parts of the proposed makarrata in which the States had an interest. That would certainly have included land.

As I pointed at the beginning of this paper, Coombs and his Committee wanted a treaty that would bind the Commonwealth to a defence of Indigenous interests from the attacks of the States. Though this point was lost in the mutual courtship of the NAC and the Fraser government over the makarrata, it was echoed by the 1983 Report of the Senate Standing Committee on Constitutional and Legal Affairs, Two hundred years later ... . The Standing Committee did not argue for or against a treaty. It merely asked: if there were a treaty, how would it fit in to the laws and constitution of the Commonwealth? The Standing Committee's preferred option was that the Constitution be altered by the addition of a Section $105 \mathrm{~B}$ enabling the Commonwealth to negotiate a compact, according to specified principles, with Indigenous Australians. Section 105B would be modelled on the existing s.105A which empowered the Commonwealth to make financial agreements with the States. When tested in the High Court in 1932, s.105A had proved robust; that is, an agreement in accordance with s.105A could not be changed by any law of the Commonwealth or the States. Section 105B would give the Commonwealth solid constitutional ground on which to stand in that it would provide that 'laws passed pursuant to the compact' would be 'binding upon the Commonwealth and the States notwithstanding anything contained in the Commonwealth or State Constitutions or in any Commonwealth or State law. ${ }^{31}$

${ }^{30}$ Aboriginal Treaty News no $1 . \quad{ }^{31}$ Commonwealth of Australia 1983: 74. 
Having set out this proposal, the Standing Committee went on to examine alternative ways that a treaty or compact might be entrenched in the Constitution. Could it come within the existing 'races' power, s.51 (xxvi) or under the 'external affairs' power, s.51 (xxix)? After pages of learned discussion of the history of judicial interpretation of those two existing powers, the Standing Committee decided that they would support 'carefully considered legislation for a compact'. However, the Standing Committee then expressed its 'concern at the political vulnerability to which any such compact legislation would be subject, due to the possibility of amendment or repeal by subsequent Parliaments. ${ }^{32}$ It was better, the Standing Committee concluded, to go for a specific head of constitutional authority modelled on the authority that secured inter-governmental financial dealings.

By 1983 the discussion on Indigenous rights had built upon late 1970s agitation over substantive policy issues such as land rights and service provision and had begun to focus on the reform of Australian federalism itself. Yet in this challenge to States rights we can glimpse the political limits of the fight for Indigenous rights, for in the 1980s there was no political vehicle for a campaign of constitutional reform. When the Keating government decided that it would legislate 'native title', the entities with which it had to negotiate the terms of native title in 1993 were primarily the States and Territories, and only secondarily the representatives of Indigenous interests.

\section{0 - the treaty debate revived}

However, the constitution remained symbolically important. So a day commemorating constitutional reform - Saturday 27 May 2000 - was chosen for a gathering known as 'Corroboree 2000', convened by the Council for Aboriginal Reconciliation (CAR) in the Sydney Opera House. Corroboree 2000 was intended as the climactic statement of the case for 'reconciliation', after ten years of discussion, policy advocacy and marketing campaigns by the Council for Aboriginal Reconciliation. What did this word mean?

Geoff Clark had been appointed a member of CAR in December 1999 and became the first elected Chairperson of ATSIC early in 2000. He brought with him to the ATSIC Chair a desire to highlight the concept of 'Indigenous rights' that was not typical of the rhetoric of CAR as it had evolved in the late 1990s. He proposed an interpretation of 'reconciliation' that was undoubtedly contentious. 'True reconciliation means recognising we possess distinct rights. ${ }^{33} \mathrm{He}$ called for the inscription, within the Constitution, of the Indigenous right of selfdetermination.

There have been no treaties, no formal settlements, no compacts.

There now needs to be. There is no mention of Australia's first peoples

in the Constitution. There now needs to be. The few rights we now

enjoy remain vulnerable in the absence of constitutional protection.

He challenged the Prime Minister with the words: 'A commitment from Government to negotiate a treaty is essential'. ${ }^{34}$

Prime Minister Howard's speech to the 'Corroboree' avoided declaring any particular understanding of 'reconciliation'. Instead he allowed that its meanings were many and personal: ' ... each of us brings our own perspective to the process of reconciliation and the one requirement that we should bring to that is the sincerity of the view that we hold on how reconciliation

\footnotetext{
32 Commonwealth of Australia 1983: 103. $\quad 34$ Sydney Morning Herald 29 May 2000.

33 Sydney Morning Herald 29 May 2000. $\quad 35$ Sydney Morning Herald 29 May 2000.
} 
might be achieved'. In specifying his own sincere understanding of 'reconciliation' he would go no further than to endorse 'practical measures to address [Indigenous] disadvantage'. ${ }^{35}$ In a later comment, the Minister for Reconciliation, Phillip Ruddock, while rejecting the term 'treaty', foreshadowed that the Howard government would work towards a 'wider framework agreement with Indigenous people'. ${ }^{36}$ The Government's line, reiterated over the next few days, was that a treaty would divide the nation, for example, by opening up disputes about land ownership. ${ }^{37}$ In saying this, the government proved more ready than Clark had been to say what a treaty might be about.

In the week following the Corroboree and the hugely popular demonstration across the Harbour Bridge, Clark was in the curious position of claiming that there was now a public mandate for a treaty, without suggesting what the treaty's principal headings might be. The government's position was a little more clear than that: the combined effect of Howard's and Ruddock's statements was to entertain a 'framework agreement' - and not a treaty - which would be about not land ownership (for that would re-open the issues of entitlement debated when the Howard government amended the Native Title Act in 1998) ${ }^{38}$ but measures to address Aboriginal 'disadvantage'.

The purpose of the Corroboree 2000 events was to bring forth an agenda of policies formulated by the Council for Aboriginal Reconciliation, a body composed of Indigenous and non-Indigenous people appointed by the Government and reflecting a variety of political outlooks. CAR's concluding proposals about public policy did not include anything as bold as Clark's call for a treaty and for constitutional expression of distinct Indigenous rights. CAR's 'Roadmap for Reconciliation' briefly described four 'national strategies' for:

— sustaining the reconciliation process

— promoting recognition of Aboriginal and Torres Strait Islander rights

— overcoming disadvantage

— achieving economic independence

The second of these four strategies, about rights, did not go as far as Clark's call for the constitutional recognition of the distinct rights of Indigenous people. On the issue of 'rights', CAR declared that its objective was for 'all Australians [to] enjoy, in daily life, a fundamental equality of rights, opportunities and acceptance of responsibilities'; and it next announced its wish that 'the status and unique identities of Aboriginal and Torres Strait Islander peoples as the first peoples of Australia, achieve recognition, respect and understanding in the wider community'. The 'Roadmap' thus refrained from linking distinct Indigenous identity with distinct Indigenous rights, and nor did it spell out the legally enforceable entitlements that made up those 'rights'. The constitutional reforms envisaged in the 'Roadmap' were also more modest than Clark's call for the entrenching of distinct Indigenous rights. The Roadmap advocated a referendum on a new preamble that would recognise 'the status of the first Australians'; and it wanted another referendum to remove s.25 of the Constitution and to 'introduce a new section making it unlawful to adversely discriminate against any people on the grounds of race'. Section 25 reads:

Provisions as to races disqualified from voting. For the purposes of the last section [on the 'constitution of the House of Representatives'], 
if by the law of any State all persons of any race are disqualified from voting at elections for the more numerous House of the Parliament of the State, then, in reckoning the number of the people of the State or of the Commonwealth, persons of that race resident in that State shall not be counted.

To remove this inactive section of the constitution would be as effectual as the removal of s.127 in 1967. As in the 1967 referendum, the deletion of anachronistic and inactive bits of the Australian Constitution would symbolise a vague and inconsequential (as far as public policy goes) expression of popular goodwill towards the First Australians. CAR's thoughts about the Constitution typified its anodyne condition in 2000.

In her Corroboree 2000 speech CAR chair Evelyn Scott used words which helped to muddy the distinction between Clark's position and CAR's: 'Our struggle for Indigenous rights and equality is bound up inextricably with the rights of all Australians. Our freedom is your freedom. ${ }^{39}$ That is, Scott alluded to 'Indigenous rights' but immediately used words ('bound up inextricably with') which seem calculated to obscure their relationship to the rights of 'all Australians'. Scott soon made it clear, however, that whatever her words in the Opera House meant, she was not in favour of a treaty. She and her deputy chair, Sir Gustav Nossal, told the Press that, unlike Clark, they did not construe the popular support for reconciliation as a mandate for a treaty. ${ }^{40}$ She described the treaty call as 'premature' and warned that 'attempts to jump stages ... will hurt rather than help take us forward'. ${ }^{41}$ Council member Jackie Huggins agreed with the Scott/Nossal reading of the unreadiness of public opinion, though she added that she was herself in favour of a treaty. However, 'a great deal more understanding, awareness and negotiation is required ...' before Australians would accept such a thing.

Our social research, publicly released earlier this year, has shown strong support for reconciliation and for a document. However, support was not so strong, for example, for calling such a document a treaty. ${ }^{42}$

Gatjil Djerrkura added his voice to this description of the 'treaty' as premature. To push for a treaty now would only alienate many people from reconciliation, he speculated. The Australian's headline for these Indigenous leaders' responses to Clark was 'reconcile now, treaty later'.

In its promotion of 'reconciliation' CAR did not challenge the public to accept a distinct Indigenous right of self-determination. Reconciliation might, in some people's understanding, entail distinct Indigenous rights, but CAR was careful to accommodate a huge variety of attributed meanings to their key term. For example, in the October 1979 issue of CAR's Walking Together, Alan Jones and Pat Dodson gave fundamentally opposed reasons for endorsing 'reconciliation'. The vague inclusiveness of 'reconciliation' was essential to its popularity by 2000, just as the unspecific commitments of the 'Yes' vote in the 1967 referendum had enabled that expression of goodwill towards Indigenous Australians to be widely popular. CAR was not willing to sacrifice the popularity of 'reconciliation' by telling the public that 'reconciliation' was ultimately to be encoded in the constitutional recognition of distinct Indigenous rights. Rather, CAR's promotion of distinct Indigenous identity was clearly qualified by a constraining theme of national unity. As Evelyn Scott reportedly said in her speech to Corroboree 2000: 'the

\footnotetext{
${ }^{39}$ Sydney Morning Herald 29 May $2000 . \quad \quad{ }^{41}$ Age 2 June 2000.

$4^{0}$ The Australian 2 June $2000 . \quad \quad 4^{42}$ The Australian 2 June 2000.
} 
new spirit of reconciliation will lead the nation to the healing and unity it requires'. ${ }^{43}$ Referring to the Harbour Bridge demonstration in her response to Clark, she used the metaphor of 'steps' to express her argument of gradualism. 'Last Sunday about a quarter of a million Australians walked together for reconciliation. As we take further steps together, let's make sure we keep and build on that support ... ${ }^{44}$

Indigenous leaders who responded in 2000 to Clark's equation of 'reconciliation' with 'treaty' used language that obscured the difference between two conflicting understandings of liberalism. In one version of liberalism, let's call it 'settler colonial liberalism', there is no place for the notion of distinct Indigenous rights. In this conception, a 'fair go' for Indigenous Australians consists of ending discrimination against them, addressing their socio-economic disadvantage by including them in the processes of wealth and income generation, and even, perhaps, giving them title to land, in recognition that their property rights have been flouted in the past. This version of liberalism was once unchallenged in Australia. It has many reforms to its credit, and its linking of the 'fair go' with national unity remains enormously appealing to a great many Australians. However, it has begun to be challenged by what we might call a 'post-colonial liberalism'. Post-colonial liberalism affirms respect for difference as the new basis for national unity. It entertains the idea that Indigenous peoples have certain rights that immigrant peoples and their descendants do not. A rewriting of the national narrative, giving prominence to themes of invasion, resistance and conquest, underpins the principle that there remain distinct Indigenous rights.

When Geoff Clark told the Corroboree 2000 audience that 'true reconciliation means recognising we possess distinct rights' he was attempting to shift the discourse of reconciliation from the homogenising themes of 'settler colonial liberalism' to the differentiating themes of 'post-colonial liberalism'. Whereas Evelyn Scott's response implied that the settler colonial liberalism (and the policy possibilities it contains) was a 'step' on the path to what Clark wanted (a step not to be rushed), Clark's assertion of distinct Indigenous rights declared a choice $-\mathrm{a}$ fork in the road - to recognise that Indigenous people had their own special claims on the state.

\section{A metaphor of nation}

At least, that is how I like to see it: a clear choice between versions of liberalism. I am aware, however, that these are academic terms of little popular appeal. What does seem to appeal is the language of healing. It is through taking up the 'healing' metaphor that some opinion leaders shifted focus from considerations of the design of the 'state' (such as the rules of our federalism) to imagining the spiritual and moral imperatives of 'nation'.

The roots of this language of nation can be seen in some of the arguments advanced in 197983 by the Aboriginal Treaty Committee. Though Coombs did not speak or write of 'healing', he had promoted a treaty as a way to remedy a flaw in Australia's nationhood. A treaty, he had suggested, would benefit all Australians, for not only would it give 'security for Aboriginal occupation of these lands', it would also 'bestow legitimacy and some colour of justice to our sovereignty over this continent ... ' It would 'bring to an end the long period of hostilities between black and white Australians, enable them to compose their differences and to embark together on a future of peace and friendship'. A treaty would form 'a kind of constitutional basis

\footnotetext{
${ }^{43}$ Canberra Times 30 May 2000. $\quad{ }^{44}$ CAR 200ob.
} 
for the relationship of Aboriginal Australians to Australian society generally'. Our occupation of this continent, he had argued, 'remains tainted and suspect'. Coombs had wanted to persuade non-Indigenous Australians that they badly needed a treaty because, without it, their nationhood was morally flawed and increasingly subject to hostile international scrutiny. The legal fiction of unoccupied land, which had long underpinned Australian law and sovereignty, was no longer supportable. ${ }^{45}$

From 1983 (I choose that date because it was when the Aboriginal Treaty Committee ceased its work) the notion persisted that Australian nationhood is deeply flawed by the 'unfinished business' of black/white relations. The bicentennial celebrations of 1988 created many opportunities to ponder the origins of Australian nationhood and to doubt the appropriateness of celebration. The High Court expressed this same dubiety in 1992 when it ruled that the Crown had always acted unfairly towards Indigenous Australians and that the whole system of land tenure must henceforth acknowledge 'native title'. Acts of redress to Indigenous Australians were framed as rectifying the foundational flaws of the nation.

When CAR presented 'reconciliation' as unifying the nation, the word 'healing' became prominent in reconciliation talk. This rise of the 'healing' metaphor in the language of Australian nationhood was boosted by the emergence into public prominence of the 'Stolen Generations', especially after the publication of Bringing Them Home in 1997..6 In 2000 some leaders and journalists specified that an official Prime Ministerial apology to the Stolen Generations was the key both to reconciliation and to healing. Healing referred to what was needed both by damaged individuals and by the nation that damaged them.

With good reason, many Indigenous Australians have presented themselves as damaged by the state's assault on their family life. Their complaint is not only of material abuse but of an insult to soul and to psyche. Many of them have acquired the terminology of sickness, recovery and healing in order to make sense of their own individual struggles against substance abuse, including alcohol abuse. Grass roots Indigenous mobilisations around substance abuse have drawn heavily on one particular therapeutic ideology: Alcoholics Anonymous. I first noticed the metaphorical extension of 'healing' in November 1994, when I attended in Sydney an international gathering of Indigenous people on the treatment of substance abuse. I could see then that 'healing' was becoming a metaphor for Indigenous empowerment. The recovery of an alcoholic, in AA therapeutic ideology, is the subject of a universalising narrative in which the individual becomes the indispensable agent of his/her recovery; he/she takes power by taking responsibility for him or herself. The AA paradigm of recovery through responsibility has proved adaptable to the Indigenous ideology of self-determination. Personal journeys from sickness and denial to self-responsibility and recovery have become a metaphor of the recovery, en masse, of a people rendered dysfunctional by colonial oppression.

Once that analogy became popular, it was not a big step to make the observation that the colonists also have been sickened by their power and must take responsibility for their own recovery. CAR's 'Australian Declaration Towards Reconciliation' used AA language when it referred to the nation's obligation 'to own the truth, to heal the wounds', and to embark on 'the journey of healing. ${ }^{47}$ These terms occurred frequently in Evelyn Scott's statements. As well, the term 'walk' rivalled the word 'march' to describe what people did on the Sydney Harbour

45 Coombs 1979a. $\quad{ }^{46}$ HREOC $1997 . \quad 47$ CAR 2000a: Appendix 1. 
Bridge and other places in May 2000. 'Walk' is another AA metaphor for displaying conviction through action: 'You can't talk the talk, if you haven't walked the walk'. In such language Scott and other CAR figures drew on the notions of personhood deployed (with therapeutic effect for many people, I should add) by Alcoholics Anonymous. Scott's press release on 1 June 2000 criticising the treaty advocates' reading of the Sydney Bridge march was headed 'The long walk to reconciliation can't jump stages'. ${ }^{48} \mathrm{CAR}$, under Scott, was 'twelve-stepping' the nation.

The notion of national recovery was foreshadowed, as I have pointed out, in Coombs's observations about Australians having to make good the moral defect in their nationhood. By drawing on the language of AA, CAR entrenched and developed that trope so that the 'healing' metaphor, by 2000, had come to signify the spiritual vicissitudes of a self that is concurrently personal, Indigenous and national. I heard this linking of recoveries in the words of a Koori man I met in April 2000 who told me that he and people like him could not commence their recovery from being members of the Stolen Generations until the Prime Minister had offered the nation's apology.

How was it possible that in the weeks leading up to Corroboree 2000 newspapers sympathetic to CAR, such as the Sydney Morning Herald, could present 'reconciliation' in terms that highlighted the personal redemption of John Howard through a Prime Ministerial apology? 'Will Howard walk?' became a resonant question.

I suggest that three factors underpinned the emergence of 'healing' as a metaphor of 'reconciliation':

1. The steady growth of an international Indigenous movement against substance abuse, drawing much of its therapeutic ideology from Alcoholics Anonymous, and involving many Indigenous Australians as both healers and healed;

2. The public ascendancy of the Stolen Generations, through the inquiry that produced Bringing Them Home, ${ }^{49}$ and the assertion, arising from that report, of the mutually healing power of the State's official apology;

3. The conservative political climate since March 1996, which encouraged attention to themes of personal redemption as an alternative to more problematic and difficult themes of institutional change. (Recall that in John Howard's Corroboree 2000 speech, he welcomed any understanding of 'reconciliation' as long as it was 'sincere'.)

It is necessary to recall how 'therapeutic' the language of 'reconciliation' had become if we are to appreciate the value of ATSIC's leadership over the next few years. ${ }^{50}$ By insisting on raising the question of the treaty in 2000, Clark provided an alternative to the fog of CAR psychobabble. Just over a week after the Sydney Harbour Bridge march in May 2000, there was a gathering of Indigenous leaders in Melbourne to discuss reconciliation strategy. It is reported to have included Geoff Clark, Marcia Langton, Charles Perkins, Peter Yu, Gary Foley, Michael Mansell, Aden Ridgeway (by phone), Ray Robinson, Pat Dodson, David Ross and Noel Pearson..$^{51}$ Evidently, the meeting endorsed Clark's call for a treaty and sketched a strategy for formulating its points of

\footnotetext{
${ }^{48}$ CAR 200ob. $\quad \quad \quad \quad{ }^{50}$ ATSIC was abolished by legislation passed in March 2005.

49 HREOC 1997. $\quad{ }^{51}$ This list is compiled from two newspaper reports, by Ben Mitchell

in The Australian 6 June 2000, and by Debra Jopson and Mark Metherell in the Sydney Morning Herald 6 June 2000.
} 
negotiation. There was mention of a 'treaty think tank ... to examine issues raised from meetings held in Indigenous communities around the country'. ${ }^{52}$ By funding a series of conferences on the treaty in 2002, ATSIC provided forums for Indigenous and non-Indigenous people to return to the questions of institutional design that are implicated in any discussion of enforceable claims - rights - and governmental accountability. Some of the results of those discussions in 2002 are to be found in this book..$^{53}$

\footnotetext{
${ }^{52}$ The Australian 6 June 2000. $\quad 53$ I have made my own observations about three public conferences supported by ATSIC in 2002 in Rowse 2003.
}

\section{References}

\section{Newspapers and Newsletters}

Age 2 June 2000.

The Aboriginal Treaty Committee Newsletter, 20 May 1980 (signed by HC Coombs).

The Aboriginal Treaty Committee Newsletter 2, October 1980.

Aboriginal Treaty News no 1, nd (most likely April 1981).

Aboriginal Treaty News no 2, August 1981.

Aboriginal Treaty News no 3, November 1981.

Aboriginal Treaty News no 4, February 1982.

Aboriginal Treaty News no 5, May-August 1982.

Aboriginal Treaty News no 6, September-October 1982.

Aboriginal Treaty News no 7, November 1982-February 1983.

Aboriginal Treaty News no 8, March-June 1983.

Aboriginal Treaty News no 9, October 1983.

Canberra Times 9 December 1980, 30 May 2000.

National Times 25 August 1979, 27 July 1980.

Sydney Morning Herald 27 November 1980, 29 May 2000, 6 June 2000.

The Australian 30 May 2000, 2 June 2000, 6 June 2000.

The Catholic Leader 13 July 1980.

\section{Books, articles and reports}

Aboriginal and Torres Strait Islander Social Justice Commissioner 2001, Social Justice Report 2000, Sydney, Human Rights and Equal Opportunity Commission.

Aboriginal Treaty Committee 1979, 'We call for a treaty - within Australia, between Australians' (advertisement), National Times, 25 August.

Brennan, Frank and James Crawford 1990, 'Aboriginality, recognition and Australian law: the need for a bipartisan approach', Australian Quarterly 62(2) Winter: 145-69.

Commonwealth of Australia 1983, Two hundred years later ... (Report by the Senate Standing Committee on Constitutional and Legal Affairs on the feasibility of a compact, or 'Makarrata', between the Commonwealth and Aboriginal people), Canberra, Australian Government Publishing Service.

Commonwealth of Australia (Senate) 1983, Standing Committee on Constitutional and Legal Affairs (reference: an examination of the feasibility, whether by way of constitutional amendment or other legal means of securing a compact, or Makarrata', between the Commonwealth Government and Aboriginal Australians), Official Hansard Transcript of Evidence.

Coombs, Herbert Cole 1979a, 'Guest of Honour Talk: ABC', CRES Working Paper: HCC/WP13.

- 1979b, 'The proposal for a treaty between the Commonwealth and Aboriginal Australians' CRES Working Paper: HCC/WP14. 
— 1980, 'Towards an end to 200 years of aggression and injustice', Amnesty address of 1979, reprinted in The National Times, 'Other Voices' column, 8-14 June.

— 1981, 'Aboriginal treaty symposium - a statement', Anthropology News 18(8) September: 117-9.

Council for Aboriginal Reconciliation (CAR) 2000a, Reconciliation: Australia's Challenge, Final Report of the Council for Aboriginal Reconciliation to the Prime Minister and Commonwealth Parliament (December), Canberra.

— 200ob, 'The long walk to reconciliation can't jump stages', press release, 1 June, available at www. austli.edu.au/au/other/IndigLRes/car259.html.

Human Rights and Equal Opportunity Commission (HREOC) 1997, Bringing them home: report of the national inquiry into the separation of Aboriginal and Torres Strait Islander children from their families, Human Rights and Equal Opportunity Commission (HREOC), Sydney.

Jopson, D and Mark Metherell 2000, 'Aboriginal leaders meet to push treaty', Sydney Morning Herald, 6 June: 7.

Mitchell, Ben 2000, 'Indigenous leaders persist on treaty', The Australian, 6 June: 2.

Pittock, A Barrie 1981, 'What's wrong with a treaty?', Identity, 4(2): 31.

Rowse Tim 2003, 'Treaty talk', Australian Policy Online, available at http://www.apo.org.au/webboard/ items/00216.shtml (posted 11 February 2003).

Wright, Judith 1985, We call for a treaty, Sydney, Collins/Fontana.

\section{Legislation}

Aboriginal and Torres Strait Islanders (Queensland Reserves and Communities Self-Management) Act 1978 (Cth).

Aboriginal Land Rights (Northern Territory) Act 1976. Native Title Amendment Act 1998 (Cth).

\section{Case law}

Koowarta v Bjelke-Petersen (1982) 153 CLR 168. 